\title{
Factors Influencing the Adoption of Internet Banking In Kenya.
}

\author{
Kariuki John Gikonyo \\ Student, Master of Science in Finance. Jomo Kenyatta University of Agriculture and Technology, Kenya School \\ of Monetary Studies.
}

\begin{abstract}
This research project seeks to improve the rare empirical knowledge on the adoption of internet banking in Kenya. Traditional branch based retail banking remains the most widespread method for conducting banking transactions in Kenya with agency banking and mobile banking being the recently adopted and widely used. However, internet technology is rapidly changing the way personal financial services are being designed and delivered.Among the major objectives of the study are, to determine how awareness of IB by the consumers affect adoption of internet banking, to determine how website security affects adoption of internet banking and to determine to what extent website features affect adoption of internet banking. The population is all the individuals who own bank accounts and currently have, those who have not adopted the internet banking as a mode of transacting. A total of 100 respondents were issued with questionnaires of which 81 were successively recovered.A random sampling was used to select the customers that would participate in the study. Content analysis and descriptive statistics was used to analyze the data. Statistical package for social science (SPSS) was used to analyze the data through the equation for best line of fit. Multi-linear regression analysis was used to test models' prediction capabilities. All hypotheses were tested at 0.05 level of significance. The result showed that more men have adopted banking than women; education level is not a barrier to the banking services, the middle-aged people have embraced the banking services than any other age category; awareness, website features and security all affect the adoption of IB.

The major recommendations of the study are; Internet banking should be adopted by both individuals and cooperates since it is inevitable in the 21st Century, and the banking institutions should also enlighten the public about internet banking.
\end{abstract}

Key words: Internet banking, adoption, Awareness, Website features, Website security.

\section{Introduction}

For over a decade, information technologies have significantly affected the banking industry all over the world. Banks and other financial institutions worldwide have improved their functions as financial intermediary through adopting various information technologies (Chang, 2002; Haynes \& Thompson, 2000; Venkateshat al. (2003).

In Africa, and more-so in Kenya due to the developing state of the economies internet is not readily accessible to most individuals willing to conduct financial transactions. But in the recent past Kenya has experienced a range on financial services through the adoption of mobile banking; these services include sending and receiving money, paying bills, account notification, balance enquiry, purchase of mobile airtime all at the convenience of the customer.

Over the recent past the greatest challenge to the adoption of technology (ICT) was the use of computers with internet connections whereby only a few individuals had access to these gargets, either those working in companies with computers with internet connections and those who really needed the service having to visit cyber cafes for access of these gargets which can be very inconveniencing. (Venkatesh et al. 2003). Now with the convenience of mobile phones with internet options that are affordable, internet banking has become more convenient since one need not own or use a computer with further the inconvenience of having to be with internet connection to access these (on-line) services.

Among various banking technologies, Internet banking, which is the act of conducting financial intermediation on the Internet (Venkateshat al. (2003) is the latest banking technology and the most rapidly diffused banking technology throughout the world.

Thus, there is a growing need for the banking sector to keep pace with the emerging requirements of the business sector by adopting appropriate technology for its effectiveness. The emphasis today is on providing banking services anywhere, anytime to anybody with the sole objective of enhancing customer outreach and flexibility in transactions (Carr, 2007).

The Internet is rapidly turning out to be a tool of worldwide communication. The increasing use of Internet earlier promoted producers and entrepreneurs to sell their products online. It has also become an important source of information and knowledge. Due to this, many banking and finance organizations have come up with the idea of Internet banking or online banking. Numerous benefits such as lower fee to go online, 
higher interest rates, online viewing of account details and statement information, pay bills, transfer money between accounts, scheduling automatic periodic payments such as rent or loan payments, applying for accounts or loans and managing loyalty points to achieve first objective(Sathye,2007). In the process, banks are able to reduce cost of operations to some extent. Nevertheless, steep rise in online banking crimes may undermined its success (vadlamani,2008).

\section{Statement of the problem}

Since the introduction of the gold and the paper money as a medium of exchange there has been a need for people to keep their money safe and to use it conveniently in conducting their transactions. Over the years the gold and money deposit takers have come up with different methods of conducting business and handling their clients as time goes and as different levels of technologies kick-in (Wambari, 2009).

Traditional branch based retail banking remains the most widespread method for conducting banking transactions in Kenya with agency banking and mobile banking being the recently adopted and widely used(Wambari,2009). However, internet technology is rapidly changing the way personal financial services are being designed and delivered. Now commercial banks in Kenya are trying to introduce internet based electronic banking systems to improve their operations and to reduce costs (Gumbo, 2010). Despite all their efforts aimed at developing better and easier internet banking systems, these systems remains largely unnoticed by the customers and certainly is seriously under-used in spite of their availability (Byoung\& Widdows,2000).

The security of information on the internet is the primary factor, which determines the adoption of Internet banking technology, (Ramakrishna, 2007).The number of malicious applications targeting online banking transactions has increased dramatically in recent years. This represents a challenge not only to the customers who use such facilities, but also to the institutions who offer them, as evidenced by an ongoing trail in the US.The possibility also exists that both approaches will be combined. Some attacks may be foiled by adopting security measures such as transaction numbers (TAN) (Kuismaat al, 2007).

Therefore this research aims at identifying the factors influencing the adoption of internet banking in Kenya, and answer questions on why there is reluctance on the adoption of internet banking.

\section{Internet Banking.}

According to comptroller's, 1999 internet banking refers to systems that enable bank customers to access accounts and general information on bank products and services through a personal computer or other intelligent device. The biggest advantage of Internet banking is that people can expend the services sitting at home, to transact business. Due to which, the account holder does not have to personally visit the bank. At an advanced level, internet banking is called transactional online banking, because it involves the provision of facilities such as accessing accounts, transfer of funds, and buying financial products or services online (Saythe, 1999). With the help of Internet banking, the account holder can execute many transactions. When small transactions like balance inquiry, record of recent transaction, etc. are to be processed, the Internet banking facility proves to be very handy. The concept of Internet banking has thus become a revolution in the field of banking and finance (Saythe, 1999).

\section{Literature Review}

Previous studies in internet banking range from (Sathye, 1999) study in Australia, (Tan and Teo,2000) research in Singapore, (Howcroft et al.2001) study in South Africa, (Chung and Paynter,2002) in New Zealand. Among the Indian internet banking researches are (Mukherjee, 2003).Several studies indicate that online bankers are the most profitable and wealthiest segment to banks (Ross, 1998; Robinson, 2000; Thorsteinson, 2000). There could be two fundamental reasons underlying internet banking development and diffusion: cost savings for banks and reduction of branch networks which has paved the way to self-service channels as quite many customers felt that branch banking took too much time and effort (Karjaluoto et al. 2003). Therefore, time and cost savings and freedom from place have been found the main reasons underlying online banking acceptance (Polatoglu and Ekin, 2001; Block et al., 2002; Howcroft et al., 2002).On the customer front internet banking provides many advantages (Pikkarainen et al, 2004; Hway-Boon and Cheng Ming Yu,2003). Time and cost savings and freedom from place have been found the main reasons underlying online banking acceptance (Polatoglu and Ekin, 2001; Black et al., 2002; Howcroft et al., 2002).Several studies have analyzed consumer adoption and growth of internet banking. 
As noted earlier, online banking offers many benefits to banks as well as to customers. However, in global terms the majority of consumers are still not using online banking channel. Reasons to this can be attributed to; new online users need first to learn how to use the service (Ross et al., 1999.) Customers have been afraid of security issues (Sathye, 1999; Hamlet and Strube, 2000; Howcroft et al., 2002). Ndubisi et al (2004) also established the importance of adequate security in order to raise the confidence of consumers to use internet banking.

\section{Internet banking in Kenya}

Banks that offer online banking services are still considered limited in the Africa when compared to Europe or the US, yet a few pioneers have emerged, notably in South-Africa, Nigeria, Zambia ,Algeria , Kenya among others (Sathye, 1999; Hamlet and Strube, 2000; Howcroft et al., 2002; Ndubisi et al.2004). As most Africa countries prepare to enter the World Trade Organization (WTO), they face the possibility of competition from multinational banks. The concern of the national banks in the African continent about loss of domestic market share has encouraged them to consider offering online banking services.

However, empirical evidence has shown that online banking services do not appear to be as widespread in Africa as in Europe and the USA and that there are many obstacles preventing the spread of adopting this technology in the Africa and in the UAE (Ndubisi et al. 2004).

There are a number of constraints - related to social and infrastructure issues - that must be taken into account when evaluating the development of online banking in Kenya. First, while many Kenyan banks may be technologically capable of offering online banking services, the telecommunications infrastructure remains deficient. Second, Internet penetration in the region is still relatively low, which may not encourage the investment required to develop online banking (Gikandi, J. \& Bloor, C., (2010).

According to a research conducted by Rotchanakitumunai, S., \&Speece, M. (2003). Barriers of Internet banking adoption: a qualitative study among corporate customers in Thailand it was noted that, many bank customers use this technology only for non-transactional activities, such as viewing account statements and balances, while bank managers want customers to use different aspects of online banking.

Generally, there are two major online banking models: The integrated approach (click and mortar) and the stand alone Internet banks, also known as "virtual" banks that have no physical branches or tellers whatsoever. Almost of the banks in the Arab world have adopted the integrated approach whereby they keep their existing brand name and offer online banking services as an extension to their other branch-based services, the ATM and the telephone (Howcroft et al. 2002). There is very low usage of internet banking among developing countries, Kenya included as noted by a search done on, Adoption of Internet Banking in the Arab world. UAE has the highest percentage of Internet users in the Arab world $(29.6 \%$ of the UAE population are Internet users), while in Bahrain Internet users represent $27.7 \%$ of the population; and in Kuwait Internet users represent 22.4\% of the population (Emirates Bank Association, 2007). The UAE banking sector is one of the most competitive sectors in the Arab world, with an estimated 46 banks (21 locally-incorporated banks and 25 foreign banks) servicing a population of approximately 4.3 million (Hamlet and Strube, 2000; Emirates Bank Association, 2007).

The number of banks offering electronic banking in the Kenya has risen steadily since the service was first launched in 1996 by Barclays Bank, with most institutions in the banking sector now providing online banking services to their customers and both on the corporate and individual level (Gikandi, J. \& Bloor, C., (2010).

\section{Conceptual Framework}

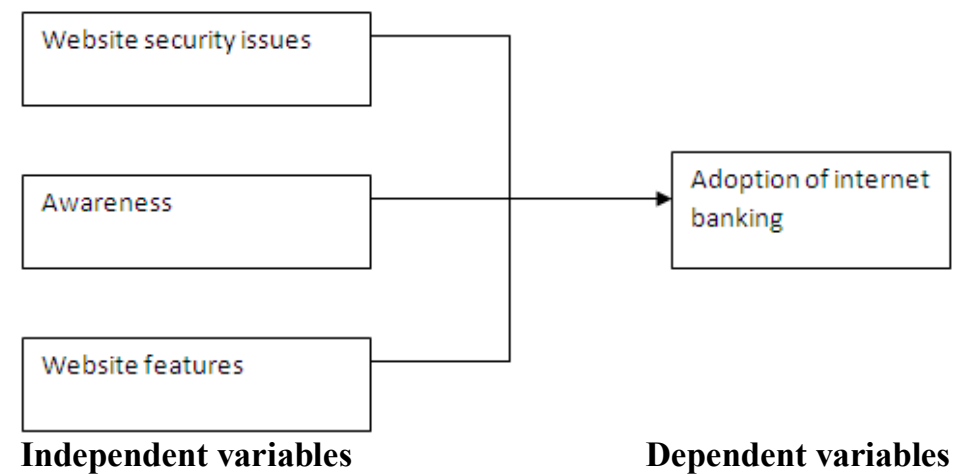




\section{Research design}

\section{Research Methodology}

The study was descriptive in nature and it involved a field survey where the researcher went out to the population of interest to find out issues relating to the problem under study. The study was descriptive because the characteristics of the phenomena studied were well known and the researcher had no control over the variables. The interest of the researcher was focused on how these can be used to achieve certain objectives in banking industry.

The descriptive study also called an explanatory study, presents data in a meaningful way that helps us to understand the characteristics of a group in a given situation, offer ideas for further probe and research, and help make certain decisions such as where the resources should be allocated given the demand in a particular area.

This study is mainly qualitative in nature. An exploratory study is research that aims to seek new insights into phenomena to ask questions and to assess the phenomena in a new light.

\section{Target population.}

In general the study was about all those individuals with different types of bank accounts in different banks and financial institutions in Kenya and in particular both those that have not adopted and those that have adopted the use of internet banking. The study seeks to determine the factors; Awareness, website security and website features that affect the adoption of internet banking in Kenya.

\section{Data collection methods and Research instrument.}

This research is primarily concerned with understanding customers' attitudes towards Internet banking in Kenya, using the constructs of the TAM as a basis. The study postulates that several factors including lack awareness, security issues, and the features of the website, will affect PU, PEOU, which in turn will affect user's attitude towards Internet banking.

This research used the survey method to test its hypotheses. A questionnaire consisting of seven parts was developed and administrated. The first part (eight questions), contains demographic data about bank customers. The next seven parts include 31 items, which have been measured using a five-point Likertscale, ranging from 1-strongly agree to 5-strongly disagree. The variables are divided as follows: four items are used to measure awareness (Awa), six items are used to measure perceived ease of use (PEOU), five items are used to measure perceived usefulness (PU), three items are used to measure website security issues (WS), seven items are used to measure features of the Website (WSF), three items are used to measure user's intention to use Internet banking (INTN), and finally three items are used to measure user's adoption of Internet banking (ACTL).

The items in the questionnaire have been developed and validated by previous TAM related research investigating IS acceptance.

\section{Data Processing and Analysis}

The data collected from the field was sorted for completeness, and summarized in tables. The process of data analysis involved several stages. Completed questionnaire was edited for completeness and consistency. The data was then coded and checked for any errors and omissions.

The data obtained from the study was coded and entered into the computer and subsequently subjected to statistical analysis using the Statistical Package for Social Sciences (SPSS). Multi-linear regression analysis was used to test models' prediction capabilities. All hypotheses were tested at 0.05 level of significance.

\section{Measurement Model}

A confirmatory factor analysis (CFA) was used to test the measurement of the proposed model. According to Hair, Anderson, Tatham and Black (1998), a factor should have a minimum of two items and each item factor loading should be greater than 0.4. The factors have been loaded as following: four items are used to measure Awareness (Awa), six items are used to measure perceived ease of use (PEOU), five items are used to measure perceived usefulness (PU), three items are used to measure website security issues (WS), seven items are used to measure website features (WSF), three items are used to measure customer's intention towards internet banking (INTN), and finally three items are used to measure customer's adoption of internet banking (ACTL).

According to Fornell and Larcker (1981), convergent validity coefficients should be higher than or equal to 0.50 . It should be noted that all convergent validity coefficients calculated for all factors in this study have been higher than 0.50 . Also, the reliability for all the factors in our model has been above 0.70 (Hair et al., 1998). 
Cronbach's alpha test is often used to measure the reliability of measures in a Likert-type scale, where multiple items are used to measure a specific research variable. There is a general agreement in the literature that a value of 0.70 and above for the Cronbach's alpha is sufficient (Nunnally, 1978; Nunnally\& Bernstein, 1994; Hair et al., 1998). As table 4.5 indicates, all the variables have an alpha of 0.75 and above, leading the researcher to conclude that their reliability is satisfactory.

\section{Conclusion}

Results from the statistical analysis provide a picture of the adoption of internet banking in the Kenyan Commercial Sector, for both individuals and the banks. The costs incurred by the customer, security of information on the internet and the government regulations on internet banking all affect the adoption of internet banking.

In conclusion costs incurred by the customer is a major factor affecting the adoption of internet banking with the highest beta coefficient of 0.659 among the factors that were under study. The reduction or review of the costs associated with internet banking, that is, internet cost, transactions cost and internet enabled costs would greatly contribute to the adoption of the internet banking.

Website security is a relatively major factor affecting the adoption of internet banking. The improvement of website security of information on the internet could go a long way in boosting the adoption of internet banking in Kenya.

\section{Recommendations of the study}

From this study, the following recommendations can be made; being in the digital era internet banking should be adopted by both individuals and cooperates since it is inevitable in the 21 st Century. The banking sector plays a major role in the shaping of the economy in all levels as most money transacted is through them. The recent technological advancement requires that every financial institution and especially banks adopts internet banking for fast service delivery.

The cost of accessing physical financial services has been found to be higher and thus internet banking can cut costs for both the customers and service providers.

The banking institutions should also enlighten the public about internet banking. This is essential for the public to be able to access and accept the technology and use it effectively to reap full benefits.

\section{Suggestions for further research}

The banking industry is key in the performance of the economy as a whole. Further research in this area is also recommended, on ways that can be used to enhance total adoption of internet banking and the benefits of internet banking. Further this research should be carried on all financial institutions SACCOS, MFIs and FSAs to determine effects of internet banking across board.

\section{References}

[1]. ABF, (1997). Banks approach market with caution. Australian Banking and Finance journal, 6(13), 9-11.

[2]. Agarwal, R., \& Prasad, J. (1999). Are individual differences germane to the acceptance of new information technologies? Decision Sciences, Vol.30,2,361-391.

[3]. Aladwani, A. (2001). Online banking: a field study of drivers, development challenges and expectations." International Journal of Information Management, 21(3), 213-25.

[4]. Araujo, I., \&Araujo, I. (2003).Developing trust in internet commerce.Proceedings of the centre for Advances Studies Conference on Collaborative Research, October 6-9, (pp. 1-15). Toronto, Ontario.

[5]. Berger, S. C., \&Gensler, S. (2007, April). Online Banking Customers: Insights from Germany. Journal of Internet Banking and Commerce, 12(1).

[6]. Block, Walter and Laura Davidson. 2010. "The Case against Fiduciary Media: Ethics is the key.” Journal of Business Ethics98, no. 3: 505-511.

[7]. Carr, M. (2007) Adoption and Diffusion of Internet Banking. A chapter in Ravi, V (ed) Advances Banking Technology and Management: Impact of ICT and CRM. IGI Global.

[8]. Chang, H.H. (2008).Intelligent Agent's Technology Characteristics Applied to Online Auctions' Task: A Combined Model of TTF and TAM. Technovation, 28(9), 564-577.

[9]. Chung, W., \&Paynter, J. (2002).An evalustion of Internet Banking in New Zealand. Proceedings of the 35th Annual Hawaii International Conference on System Sciences (HICSS'02), 7, p. 185.

[10]. Clarke, A., Ensor, B., \& Camus, L. (2008, April 15) Investors Don't Understand the Importance Of Online Advice Tools.

[11]. Davis, F. D., Bagozzi, R. P., \&Warshaw, P. R. (1989). User acceptance of computer technology: A comparison of two theoretical models. Management Science, 35(8), 982-1003.

[12]. Davis, K, Bagozzi, M \&Warshaw, H: (1989) User acceptance of computer technology: A comparison of two theoretical models. Management Science.Vol. 35, No. 8, Sweden.

[13]. Diniz, E. (1998). Web banking in the USA. Journal of Internet Banking and Commerce.

[14]. Gerrard, P., \& Cunningham, J. B. (2003).The diffusion of internet banking among Singapore consumers. The International Journal of Bank Marketing, 21(1), 16-28.

[15]. Gikandi, J. \& Bloor, C., (2010).Adoption and effectiveness of electronic banking in Kenya. Journal of Electronic Commerce Research and Applications 9 (2010) 277-282 
[16]. Jayawardhena, C., \& Foley, P. (2000). Changes in the banking sector: The case of Internet banking $\mathrm{n}$ the UK. Internet Research: Electronic Networking Applications and Policy, 10(1), 19-30.

[17]. Kalakota, R., \& Robinson, M. (1999).e-Business, Roadmap for Success, Addison-Wesley Reading, USA.

[18]. Midgley, G. (1992).The sacred and profane in critical systems thinking. Systems Practice, 5(1), 5-16.

[19]. Mols, N. P. (1998).The internet and the banks, strategic distribution channel decisions. International Journal of Bank Market ing , $116(5), 195-201$

[20]. Noteberg,A. E., Christiaanse, \&Wallage, P. (2003). Consumer trust in electronic channels. E-service Journal, 2(2), 46-68.

[21]. Oliga, J. C. (1991). Methodological Foundations of Systems Methodologies. In R. L. Flood \& M.C. Jackson, Critical Systems Thinking: Directed Readings, (pp. 159-184)..Chichester, UK: Wiley.

[22]. Olson, J. C., and Dover, P. A. 1979. "Disconfirmation of Consumer Expectations through Product Trial," Journal of Applied Psychol-ogy(64:2), pp. 179-189.

[23]. Robinson, S. L., and Morrison, E.W. 2000."The Development of Psychological Contract Breach and iolation: A Longitudinal Study," Journal of Organizational Behavior (21:5), pp.525-546.

[24]. Ross, M. 1989. "Relation of Implicit Theories to the Construction of Personal Histories," Psychological Review (96:2), pp.341 -357.

[25]. Rotchanakitumunai, S., \&Speece, M. (2003). Barriers of Internet banking adoption: a qualitativestudy among corporate customers in Thailand. International journal of Bank Marketing21(6-7), 312-323.

[26]. Verma, S.Y., \&Agarwal, N. (2004). Cyber branding: an exploratory study of virtual organizations. Journal of Internet Banking and Commerce, $9(3)$.

[27]. Wambari, T (2009) Mobile banking in developing countries. A case study on Kenya.

[28]. York, J., \&Pendharkar, P. C. (2004). Human-computer interaction issues for mobile computing in a variable work context. International Journal of Human-Computer Studies, 60, 771- 797.

[29]. Young, R. D., Lang, W. W., \&Nolle, D. L. (2007).How the Internet affects out-put and performance at community banks. Journal of Banking \& Finance, 31, 1033-1060. 